\title{
The Persistence of Social Norms, Family Formation, and Gender Balance in Politics
}

\section{Moa Frödin Gruneau (10)}

\section{University of Gothenburg}

Throughout history, most positions of political power have been held by men, and despite numerous laws and regulations aimed at increasing gender equality in society and politics, the majority of democratic assemblies remain predominantly composed of men. What makes this gender composition persistent over time? Using data from Swedish population registers from 1982 to 2014 and demographic statistics from 1749 to 1859 , I study how historical social norms shape the present-day gender balance in local politics. The results show that where family formation was more traditional in the past, there are fewer women in local politics today. The analysis also shows that family formation is a likely mechanism for the transmission of social norms across generations. The findings contribute to our understanding of the historical persistence of social structures and the reasons why gender balance in politics is not easily achieved.

Keywords: Representation, gender, marriage markets, history, social norms

W

hat explains the persistence of male-biased compositions of political assemblies? A fast-growing literature in economics on the origins of gender norms shows that history matters for shaping gender roles and that such norms often persist over long periods (see Giuliano 2017 for an

I thank Jenny de Fine Licht, Mikael Persson, Johanna Rickne, Peter Esaiasson, Andrej Kokkonen, Elin Naurin, Frances McCall Rosenbluth, Mona Morgan-Collins, and Alexandra Cirone; participants at the Swedish Political Science Association's Annual Conference in 2018, EGENEurope 2019, the European Conference on Politics and Gender in 2019, the Gothenburg Research Group on Elections, Public Opinion and Political Behavior internal conference, and the General Research Seminar of the University of Gothenburg's Political Science Department; and three anonymous reviewers for feedback on previous versions of this article.

(c) The Author(s), 2021. Published by Cambridge University Press on behalf of the Women, Gender, and Politics Research Section of the American Political Science Association. This is an Open Access article, distributed under the terms of the Creative Commons Attribution licence (http://creativecommons.org/licenses/by/4.0/), which permits unrestricted re-use, distribution, and reproduction in any medium, provided the original work is properly cited. doi:10.1017/S1743923X21000106 
overview). This research has provided valuable insights into the persistence of gender norms; however, the focus is primarily on other outcomes than gender balance in politics.

In this article, I use Sweden, one of the most gender-equal countries in the world, to study whether the persistence of historical social norms can shed light on why some places have reached a higher level of gender balance in politics than others. Studying within-country variation in gender balance in politics is advantageous in several ways. First, cross-country studies show that a substantial part of the variation in attitudes toward women's work outside the home is due to laws, regulations, and family policies (Sjoberg 2004) and that the type of political system has an impact on women's political representation (Iversen and Rosenbluth 2010). Focusing on Sweden, national-level policies and the political system are constant. Second, the social structure and the degree to which gender norms are traditional vary extensively within Sweden (Forsberg 1997). Third, using administrative register data from 1982 to 2014 (Statistics Sweden) and historical registers from 1749 to 1859 (Tabellverket 2018), I study the persistence of social norms measured as family formation structures - specifically, the shares of women and of unmarried women - across a larger time span than previously studied.

I theorize that present-day gender balance in politics goes hand in hand with deeply rooted patterns in family formation structures, such that contexts that emphasize women's responsibilities in the household will be associated with a lower likelihood of women pursuing politics. In this article, I focus on the role of family formation structures in the transmission of social norms across time. The importance of the transmission of behavior, attitudes, and social norms across generations has been highlighted in both economics (Fernández and Fogli 2009; Fernández, Fogli, and Olivetti 2004) and political science (Jennings 2007; Verba, Schlozman, and Burns 2005). Values, such as gender attitudes, and behavior, such as political participation, are transferred from parents to children across generations (Westholm 1991; Westholm and Niemi 1992). Family formation happens in all generations, is influenced by the parents, and is a gendered process in which daughters learn from their mothers and sons from their fathers (Fernández, Fogli, and Olivetti 2004).

The structure of the marriage market determines the degree of specialization within heterosexual households in terms of market and nonmarket work (Becker 1973), and where traditional gender norms are 
prevalent, women tend to face a trade-off between work and family (Bertrand et al. 2016). Moreover, traditional gender norms explain why women show less political ambition than men (Lawless 2005): traditional family structures often put more constraints on women in politics (Bernhard, Shames, and Teele 2020; Folke and Rickne 2020), and traditional gender norms may result in a demand for politicians with traditional family structures (Gimenez et al. 2018; Teele, Kalla, and Rosenbluth 2018). Thus, family formation plays an important role in both transmitting social norms and explaining why gender equality in politics is not easily achieved. Yet, previous research on women's political representation has largely overlooked the importance of historical patterns of family formation.

In this article, I study two interconnected research questions. First, can the historical persistence of social norms of gender equality explain why some places achieve a higher level of gender balance in politics than others? Second, does family formation play a role in transmitting social norms of gender equality across time? To answer these questions, I combine data from Swedish administrative registers and historical parish registers. The administrative register data provide an excellent opportunity to measure gender balance in local politics (elected and nominated candidates) and family formation, as they contain demographic and socioeconomic statistics on all Swedish working-age citizens and politicians. The historical data represent a unique source of detailed demographic statistics collected by parish priests, which I use to measure demographic preconditions as a proxy for historical social norms.

To measure the extent to which historical social norms of family formation were traditional, I rely on two demographic proxy variables: the share of women in the population and the share of unmarried women in the population. The larger the share of women, the more likely women are to take up work traditionally seen as male, thus altering gender roles (Manning 1990; Teso 2018). The share of unmarried women in a population can be thought of as an extension of this logic. Where marriage rates are low, norms are less traditional (Pessin 2018). In a series of regression models, I study the correlations between family formation in the past, family formation today, and gender balance in politics today. The results show that in places with a history of traditional family formation patterns, there are fewer women in politics today. Where family formation patterns were traditional in the past, family formation patterns are more likely to be traditional today. 


\section{FAMILY FORMATION MATTERS FOR GENDER BALANCE IN POLITICS}

A large body of research in political science seeks to explain women's underrepresentation in political assemblies. Following the work of Norris and Lovenduski (1995), many scholars focus on the factors that explain why women run for political office or why people support female candidates. Such explanations highlight the importance of traditional gender norms, which can account for both the lack of supply and the low demand for women in politics through several different channels. For example, traditional norms can lower supply by affecting women's ambition to run for office (Fox and Lawless 2004; Lawless 2005), putting constraints on female politicians (Bernhard, Shames, and Teele 2020; Folke and Rickne 2020), and they can lower the demand for women in politics, making voters less likely to vote for female candidates (Gimenez et al. 2018; Teele, Kalla, and Rosenbluth 2018).

One reason why traditional gender norms and family structures may constrain women from political activity is that identity - the way people think of themselves - sets social expectations of individual behavior. Akerlof and Kranton (2000) present a model in which utility is gained by complying with social norms, such as a man earning more than his wife and doing a smaller share of the household tasks. If a woman earns more than her husband, the utility of marriage decreases by not complying with the norm. Household utility can be increased if the woman takes on more than half of the housework. Thus, if gender norms are traditional, it is expected that women in dual-earning households will do a larger share of the housework. When women and men are equally likely to work full-time, but women spend more time on household tasks, we can expect that women will have less time for other activities, such as running for local office. ${ }^{1}$

A traditional family structure, also in the case where dual-earner households are common, is expected to put larger constraints on women's possibilities for political participation than on men's. Folke and Rickne (2020) show that women who are promoted to top political positions are more likely to get divorced than men in the same situation. In addition, they show that it is primarily women living in gendertraditional marriages who experience divorce as a result of promotion.

1. This argument applies to households formed by two adults; having children would most likely affect the magnitude of the constraints put on women. Single-person households or single parents may face different constraints. 
Bernhard, Shames, and Teele (2020) show that among politically ambitious women - the likely candidates - women who are mothers and/or breadwinners are less likely to actually run for office. Higher risk of personal costs when running for political office can influence women's incentives to become politicians.

We know from previous research that traditional gender norms and gendertraditional family structures help explain women's underrepresentation in politics. However, it is less clear what explains variations in such traditional norms and structures.

\section{SOCIAL NORMS PERSIST OVER TIME}

Recent literature in political science highlights that historical institutions and events matter for present-day political attitudes (Acharya, Blackwell, and Sen 2016; Homola, Pereira, and Tavits 2020; Mazumder 2018) and institutions (Broms and Kokkonen 2019). At the same time, a growing literature in economics is concerned with the historical origins of gender norms (Alesina, Giuliano, and Nunn 2013; Giuliano 2015; Hansen, Jensen, and Skovsgaard 2015; Olivetti and Petrongolo 2016). Agriculture, demographics, geography, preindustrial societal characteristics, and family structures, among other things, have long-term consequences for modernday gender equality (see Giuliano 2017 for an overview).

In an influential study, Alesina, Giuliano, and Nunn (2013) argue that gendered patterns of preindustrial labor division can explain traditional gender roles today. In agricultural societies using the plough, for example, there was a sharper division of labor between men (strong enough to use the plough) and women, compared with agricultural societies not using the plough, where a gendered division of labor was less beneficial (Boserup 1970). The use of the plough has had a longterm impact on women's labor force participation (Alesina, Giuliano, and Nunn 2013) and family formation patterns (Giuliano 2015).

In addition, scholars have highlighted the long-term effect of historical population sex ratios on contemporary attitudes. For example, Brodeur and Haddad (2018) find that the U.S. counties that were part of the nineteenth-century gold rush exhibit more tolerant attitudes toward homosexuality today. They suggest that extremely male-biased sex ratios and the presence of fewer religious institutions during the gold rush led to persistent liberal values and lower levels of religiosity. Another study by Baranov, De Haas, and Grosjean (2018) uses eighteenth- and 
nineteenth-century convict transportation in Australia to study the effects of male-biased sex ratios. They find that areas that were male-biased in the past were more likely to vote against same-sex marriage in a recent referendum. They argue that the areas that were male-biased in the past developed strong masculinity norms that have persisted over time. Thus, the results are contradictory, showing that a history of male-biased sex ratios in some cases leads to more liberal values, but in other cases to less liberal values. However, what is common in both studies is that historical events and preconditions have long-lasting impacts on social norms.

Previous research has studied how history matters for a wide range of present-day outcomes, in both economics and political science. One of the main takeaways from this literature is that historical preconditions can affect social norms, which can be persistent over extensive periods of time. Yet, the possible link between historical family formation and the present-day gender balance in political representation has not been given much attention.

\section{FAMILY FORMATION TRANSMITS NORMS ACROSS GENERATIONS}

Growing up in a gender-equal household may influence one's future choices. Studies show that parental role models matter for women's labor force participation, among other things, and that attitudes about family roles are transmitted from parent to child. Intergenerational transmission of norms can thus be seen as a mechanism that explains how social norms persist over long periods.

The literature on cultural differences in gender norms shows that individuals who grow up in the same country but with different parental backgrounds have different attitudes about gender roles, different labor force participation rates, and different fertility rates (Antecol 2000; Blau et al. 2013; Fernández and Fogli 2009). The argument is that if attitudes and social norms did not influence an individual's life choices, moving from one context to another would lead to an instant change in behavior. However, if social norms influence one's behavior, changing the context one lives in will not (entirely) change one's attitudes and opinions.

One influential example showing that attitudes toward gender roles are transmitted across generations through family formation is provided by Fernández, Fogli, and Olivetti (2004). These authors study how random 
shocks to one generation of women's labor market participation influences the labor market participation of the next generation of women. More specifically, they show that men who grew up with a working mother are more likely to form dual-earner relationships later in life. Fernández (2013) develops a theoretical argument for how norms matter for women's increasing labor market participation over time. The parental generation provides information that the next generation of women uses to compare the cost of working with the benefits of the labor earnings. The cost of working is influenced by social norms about gender roles.

This literature shows that family formation plays an important role in the transmission of gender norms across generations. However, the main focus is the labor market rather than gender balance in politics.

\section{STUDYING LOCAL-LEVEL VARIATION IN SWEDEN}

The Swedish case should in many ways be ideal to test whether historical persistence matters for present-day gender balance in politics. First, Sweden has no electoral law that requires political assemblies to be gender balanced (Freidenvall 2006). Second, Sweden's 290 municipalities have independence when it comes to taxation and the provision of welfare services, and they employ a large share of the Swedish workforce. Third, Sweden has numerous policies aimed at easing the work-family trade-off for women, such as individual taxation and subsidized child care (Boschini et al. 2011). Thus, there is variation in the dependent variable and a degree of municipal independence. However, the active promotion of gender equality by the state should make Sweden a relatively difficult test. If we can find persistent structures in the Swedish case, where numerous policies at the national level have promoted gender equality, it is likely that such persistent structures are also prevalent in countries where such policies are less common.

Swedish municipalities are governed by municipal councils, to which politicians are elected through a proportional representation system using party lists with nominated candidates. ${ }^{2}$ If women are placed in nonelectable rankings on the party lists, it is possible to nominate a large

2. Proportional representation systems are more likely to produce gender balance than majoritarian systems because they are less competitive. In proportional representation systems, more parties compete with each other. If gender balance is seen as an issue that can attract voters, many parties will adopt this strategy (Kittilson 2006; Lovenduski and Norris 1993; or see Wängnerud 2009 for a review). 
proportion of women without affecting the gender balance among elected politicians.

On average, Swedish municipalities have achieved gender balance in political representation, yet there is a large variation in the gender composition of the municipal councils. Historically, the number of women in Swedish politics was very low until the 1970s. Since then, two periods have seen sharp increases in women's representation. First, women's representation in Parliament increased from 14\% in 1970 to $28 \%$ in 1979. ${ }^{3}$ Following that, many political parties introduced so-called zipper quotas, causing women's representation in the municipal councils to increase from an average of $33 \%$ in 1991 to $41 \%$ in 1998. These developments can be seen as evidence that numerous national-level policies have successfully promoted gender equality over the years; however, at the local level, the differences in gender balance in politics are substantial, ranging from $9 \%$ to $50 \%$ in the early 1990 s and from $30 \%$ to $57 \%$ in 2014.

Political parties are important for explaining local variation in women's political representation. Some parties are more likely than others to nominate women. In municipalities with a large presence of such parties, it is likely that there will be more women (Freidenvall 2006). However, although many parties have used some sort of soft quotas since the 1970s, such as party recommendations on gender balance, compliance with these strategies has not always been perfect at the local level (Freidenvall 2006). ${ }^{4}$ In this article, I study the time period from 1982, which follows the first wave of increasing women's representation, to 2014 .

Figure 1 shows the variation in the proportion of women elected and nominated over time across Swedish municipalities. The average increased substantially between 1991 and 1994 (when many of the parties introduced stricter quotas). Although the average is high, there is substantial variation across municipalities, and this is the case in both the earlier and later years included.

3. The main reason for the increase can be found in party strategy, where parties competed with each other to be the party with the largest share of women (Freidenvall 2006).

4. Freidenvall (2006) provides evidence from case studies suggesting that one reason for varying compliance was variation in the importance of other aspects of representation. Where geographical representation within municipalities was held to be more important than representation based on sex, parties sometimes found ways not to implement the rules from the central party organization. 
Gender balance in municipal councils
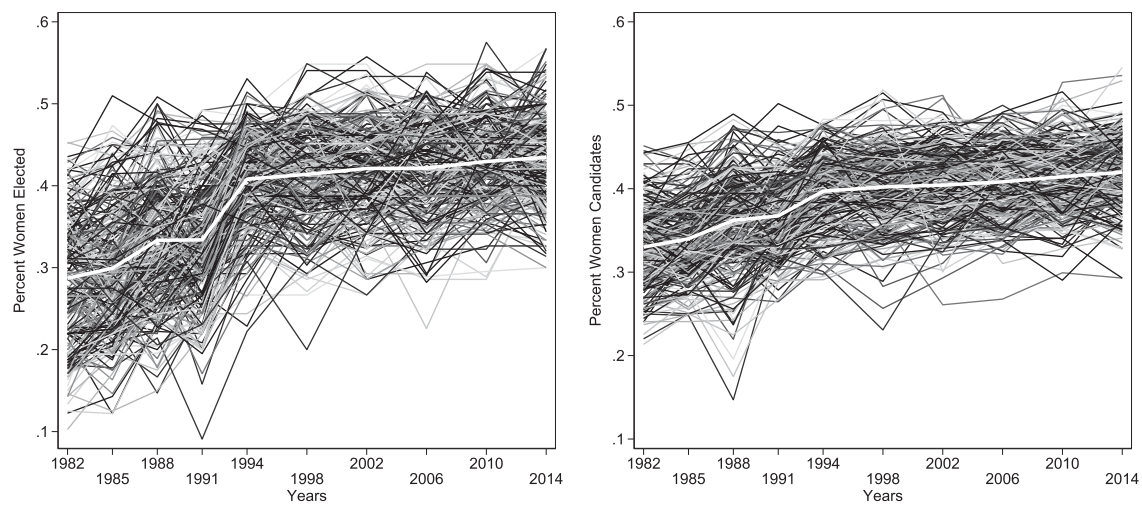

Figure 1. Gender balance in local politics. Proportion of women in local office and among candidates, all elections 1988-2014. The gray lines represent municipalities, and the white line shows the average of all municipalities. Source: Statistics Sweden.

\section{THE PERSISTENCE OF SOCIAL NORMS, FAMILY FORMATION, AND GENDER BALANCE IN POLITICS}

In this article, I aim to provide new insights into why the gender composition of political assemblies is not easily changed. In spite of numerous national-level policies promoting gender equality, there is extensive variation in gender equality in political representation across Swedish municipalities. I use this variation to study whether history matters for gender balance in local politics today. I suggest that historical social norms help explain the persistence of male overrepresentation in politics and that family formation plays a key role in transmitting social norms across time.

I use data from before and after the introduction of democracy. Reaching as far back as the eighteenth and nineteenth centuries is advantageous as local variations in family formation and social norms at that time were not influenced by democratic policy decisions. Moreover, if there were differences in social norms across municipalities at that time, those differences cannot be transmitted across time through variation in gender balance in local political assemblies. However, family formation is, by definition, present in all generations, regardless of who decides policy, and could transmit such norms across time. This logic is presented in the following diagram. There is no direct arrow from historical social 
norms to gender balance in politics - the time gap makes the direct relationship logically unreasonable.

Historical social norms $\rightarrow$ Family formation $\rightarrow$ Gender balance in politics

I study the relationships between historical social norms, family formation, and gender balance in politics separately. I have theoretical expectations for all three correlations. The first hypothesis concerns the (indirect) relationship between historical social norms and gender balance in politics today. I expect there to be fewer women in politics in municipalities with a history of more male-biased social norms. The other two hypotheses focus on how this indirect relationship can be explained - in other words, the suggested mechanism of norm transmission. The second hypothesis concerns the present-day relationship between family formation and gender balance in politics. As family constraints may hinder women's political representation, I expect more traditional patterns of family formation to correlate with low numbers of women in politics. The third hypothesis concerns the relationship between historical social norms and present-day family formation. I expect more traditional patterns of family formation today in municipalities with a history of more male-biased social norms.

$\boldsymbol{H}_{\mathbf{l}}$ The more male-biased historical norms are, the fewer women there will be in politics today.

$\mathrm{H}_{2}$ The more traditional family formation is today, the fewer women there will be in politics today.

$\mathrm{H}_{3}$ The more male-biased historical norms are, the more traditional family formation will be in the population today.

\section{DATA}

I use both contemporary administrative data from Statistics Sweden (all election years, 1982-2014) and historical data from Swedish parish registers (1749-1859). The data were combined using geocodes from the Swedish National Archives (Riksarkivet). The data were chosen with two main considerations in mind. The first and most important was to cover the longest time span possible. The longer the time span, the less likely it is that we will find persistence. If there is persistence over such a long time period, persistence is also likely across a shorter time span. Second, 
to keep the measurements as coherent as possible, I chose to rely on a single source of data for each time period.

The data for the contemporary analysis consist of individual-level register data kept by Statistics Sweden on the Swedish population, political candidates, and elected politicians for all election years from 1982 to 2014. The data contain information on all politicians nominated and elected to municipal councils in all elections from 1982 to 2014 (more than 200,000 unique individuals), and they are linked to registers of the working-age population (1988-2014) that contain information on education, income, and age, among other things. ${ }^{5}$ Moreover, the data permit linking married individuals to each other. ${ }^{6}$ The main benefits of the data are that it is possible to construct detailed measures of local variation of family formation structures and to measure gender balance among the nominated and elected politicians in all Swedish municipalities. Aggregating the data to the municipal level gives more than 2,700 observations from 290 municipalities in 10 elections. $^{7}$

The historical analysis uses data from Swedish parish registers (Tabellverket 2018). Tabellverket was founded in 1749 by the Swedish state with the aim of collecting population statistics. The data were collected for approximately 2,500 parishes by parish priests and sent to the central authorities. In 1859, Tabellverket's mission was taken over by Statistics Sweden. No other country except Finland has continuous population data reaching as far back in time. Containing detailed demographic statistics of the Swedish population collected from 1749 to 1859, the data permit analyses of demographic developments at the local level during early industrialization and before the introduction of democracy. The data contain information on demographics, mortality, migration, and occupation, divided by sex, age, and civil status. ${ }^{8}$ Using all available data from the time period, the historical data are aggregated to areas that correspond with the borders of present-day municipalities.

5. The administrative data changed format in 1990. In order to rely on the same source of data for the entire time period, all models using data on contemporary family formation are limited to 1988-2014 (for 1988, I use data from the closest year available, 1990). Bivariate models using historical data and gender balance in politics can use consistent measurements as far back as 1982 .

6. Unfortunately, cohabitation is not perfectly measured, limiting the analysis to married couples. As conservative norms may be related to the share of married/cohabiting couples, it is not ideal to exclude cohabiting couples.

7. The number of municipalities increased during this period, from 283 municipalities in 1982 to 290 municipalities in 2014.

8. There are some missing values in the historical registers; however, data most likely are not missing in any systematic way. There is no available information on the exact reasons for missing values. Some registers are missing data because of fires, but not all reasons for missing data are accounted for. 


\section{MEASUREMENTS}

The two dependent variables used in the analysis are gender balance in political representation and gender balance in political candidacy. Gender balance in descriptive political representation is measured as the proportion of women among elected municipal councilors, $\frac{w_{m t}^{e}}{t_{m t}^{e}}$, where $w_{m t}^{e}$ is the number of women elected in a specific municipality in an election and $t_{m t}^{e}$ is the total of elected individuals in a specific municipality in an election. Gender balance in political candidacy is measured as the proportion of women among individuals nominated to municipal councils, $\frac{w_{m t}^{n}}{t_{m t}^{n}}$, where $w_{m t}^{n}$ is the number of women nominated in a municipality in an election and $t_{m t}^{n}$ is the total of nominated individuals in a municipality in an election.

To measure social norms of family formation, historically and today, I rely on a number of proxy variables measuring family formation structures. The main benefits of the proxy variable approach are that I can use the same types of measurements for both the present-day and historical data analysis and that Swedish administrative registers provide high-quality data. Another more direct approach to measuring social norms would be to use survey data. However, for obvious reasons, there are no such data available for the historical period, and using contemporary survey data would yield very few answers in smaller municipalities. Previous research has found a correlation between marriage rates among skilled and unskilled women and gender norms measured in surveys (Bertrand et al. 2016); thus, the proxy variables should be valid measurements of gender norms.

The main independent variables are two proxy variables of historical social norms of family formation: the proportions of women and unmarried women in the population. Previous research on the historical sex ratio shows that where women outnumbered men, women were more likely to take up what is traditionally seen as male work, thus altering gender roles (Manning 1990; Teso 2018). The proportion of unmarried women in the population can be seen as an extension of this logic: it is expected that where there is a large proportion of unmarried women, gender norms are less traditional (Pessin 2018). Moreover, marriage formation patterns are often seen as a result of geographic differences in social norms in the case of Swedish history. For example, Lundh (2013) finds that social norms play an important role in explaining variation in women's age at first marriage in Sweden from 
1870 to 1900, and Morgan-Collins and Natusch (2020) show that the type of neighborhood is crucial to women's voting participation in early democracy. In the absence of historical survey data, I measure the proportion of women as $\frac{w_{m}}{a l l_{m}}$, where $w_{m}$ is the number of women in a municipality and $a l l_{m}$ is the total population in a municipality. I measure the proportion of unmarried women as $\frac{u n_{m}^{w}}{a l l_{m}^{w}}$, where $u n_{m}^{w}$ is the number of unmarried women and $a l_{m} w$ is the total number of women in a municipality.

The main variables in the present-day analyses are three measurements of family formation: marriage rate, divorce rate, and age gap in couples. Previous research has found that marriage rates are commonly lower where gender norms are less traditional (Pessin 2018), since women face difficulties in combining work and family life when entering the labor market (McDonald 2000). ${ }^{9}$ I measure the marriage rate as $\frac{w_{m t}^{m}}{w_{m t}^{m}}$, where $w_{m t}^{m}$ is the number of married women in a municipality and $w_{m t}^{a}$ is the number of women in a municipality at each election year. A second commonly used measure of traditional family formation is the divorce rate among women. It is expected that divorce rates will be higher where norms are less traditional (Aguilar-Gomez and Benshaul-Tolonen 2018; Bertrand, Kamenica, and Pan 2015; Stevenson and Wolfers 2007). ${ }^{10}$ I measure the divorce rate as the proportion of women who are divorced, $\frac{w_{m t}^{d}}{w_{m t}^{a}}$, where $w_{m t}^{d}$ is the number of divorced women in a municipality and $w_{m t}^{a}$ is the number of women in a municipality at each election year. A third commonly used measurement of traditional family formation is the age gap between spouses. It is expected that the larger the age gap, the more traditional the social norms of family formation. A large age gap in this literature is interpreted as women having less bargaining power in the relationships (see Rotering and Bras 2019 for an overview). I measure the age gap as the average age difference between married

9. However, recent increases in marriage rates in many developed countries (such as Sweden) contradict this story. Some scholars now argue for a U-shaped relationship between gender norms and marital stability (Esping-Andersen and Billari 2015; Goldscheider, Bernhardt, and Leppegård 2015). For example, this U-shaped relationship is restricted to groups with high education in the United States, while a negative relationship is found among those less educated (Pessin 2018). In other words, although a reverse or U-shaped relationship is expected among some groups in society, on average, the relationship is expected to be negative. Thus, I expect that the marriage rates will be lower if gender norms are less traditional.

10. Sweden has had a no-fault divorce law since 1915, and since 1974 the only restriction is that married couples with children younger than 16 are required to observe a six-month waiting period until the divorce can be finalized (for an overview, see Simonsson and Sandström 2011). 
women and their spouses, $\frac{a g e_{m t}^{m w}-a g e_{m t}^{s}}{w_{m t}^{m}}$, where age $e_{m t}^{w m}$ is the age of a married woman, age ${ }_{m t}^{s}$ is the age of her spouse, and $w_{m t}^{m}$ is the total number of married women in a municipality at the time of an election. ${ }^{11}$

In addition to the main variables of interest, I include a number of geographical time-invariant covariates and historical economic covariates: coordinates for latitude, coordinates for longitude, region, and the natural $\log$ of the area (in square kilometers) of the municipality. Another historical covariate included is the proportion of individuals employed in industry. ${ }^{12}$ The time-invariant and historical covariates are used to exclude other explanations that may influence present-day outcomes. For example, agricultural potential and historical economic specialization may directly affect present-day outcomes. Adding covariates for latitude, longitude, and region reduces the risk of bias from geographic conditions, and adding the covariate for historical employment in industry can be thought of as a catchall variable for economic conditions related to early industrialization.

In models using only present-day data, I include additional contemporary covariates: the municipal population, average income, and the share of seats for the Social Democrats and the Left Party. More populous municipalities are expected to be more urban and have more progressive values. The same is expected for municipalities with higher average incomes. Left-wing parties are expected to nominate a larger share of women candidates. Summary statistics of all variables included can be found in Table $1 .{ }^{13}$

\section{MODELING STRATEGY}

Can historical social norms predict present-day gender balance in politics? Because of the long time span between the historical measure and the contemporary outcome, a correlation between the two may be interpreted as the persistence of social norms. The extensive amount of detailed, high-quality data provides many different modeling options. Despite this, I have chosen to keep the analysis simple in the sense that I focus on the aggregate (municipal) level only, and the analysis is

11. I chose to focus on the divorce rates and the age gap in women's relationships and not men's (or the average) because of different remarriage patterns among women and men.

12. Non-agricultural, all types of employments, all industrial sectors. The details of the data vary by year and type of parish, and, in most cases, women are not included in the occupational data.

13. Additional descriptive statistics can be found in the online appendix, Section 1. 
Table 1. Descriptive statistics

\begin{tabular}{lcccc}
\hline & Mean & SD & Min & Max \\
& & & & \\
Dependent variables 1982-2014 & 0.379 & 0.082 & 0.091 & 0.575 \\
$\begin{array}{l}\text { Proportion women elected } \\
\text { Proportion women nominated }\end{array}$ & 0.385 & 0.053 & 0.147 & 0.545 \\
Independent variables 1988-2014 & & & & \\
Marriage rate & 0.480 & 0.057 & 0.296 & 0.660 \\
Divorce rate (crude) & 0.104 & 0.027 & 0.030 & 0.174 \\
Age gap in couples & 2.876 & 0.287 & 2.103 & 3.967 \\
Population & 23,608 & 45,674 & 1,839 & 674,431 \\
Proportion left parties elected & 0.451 & 0.121 & 0.067 & 0.829 \\
Average income (Swedish kronor) & 1,276 & 386 & 740 & 3,967 \\
Historic variables 1749-1859 & & & & \\
Proportion unmarried women & 0.241 & 0.026 & 0.175 & 0.358 \\
Proportion women & 0.520 & 0.024 & 0.457 & 0.861 \\
Proportion employed in industry & 0.032 & 0.039 & 0.000 & 0.208 \\
Geographic variables & & & & \\
Area of municipality (log) & 21.027 & 1.328 & 16.452 & 24.727 \\
Latitude & 59.346 & 2.728 & 55.421 & 68.165 \\
Longitude & 15.315 & 2.448 & 11.294 & 23.774 \\
\hline
\end{tabular}

Notes: The table displays the mean, standard deviation, minimum, and maximum values of the main variables used in the analysis. The present-day data include observations for each municipality and election year. The historical and geographic data have one observation per municipality.

Sources: Statistics Sweden and Tabellverket.

correlational. The main strength of this approach is that it provides a clear description of the relationship between historical gender norms, measured as family formation patterns, and gender balance in present-day politics over a span of more than 260 years. The main drawbacks of the modeling choice are the lack of precision and detail and the inability of the modeling strategy to identify the reason for the differences across municipalities. The use of proxy variables to measure social norms means that I cannot rule out explanations other than norms (e.g., path dependency in resources) as the reason for long-term persistence. In other words, the aim of the analysis is to draw a larger picture by establishing correlations, but the analysis cannot pinpoint the precise magnitude of the causal relationship or rule out alternative mechanisms with certainty.

The main analysis in this article consists of a series of ordinary least squares (OLS) regression analyses of the correlations between the historical family formation structures and present-day gender balance among elected and nominated politicians (corresponding to $\boldsymbol{H}_{\boldsymbol{l}}$ ). 
The contemporary data are panel data, but the historical measure is an average that is measured once for each municipality. Thus, the data can be thought of as a panel in which the historical measurements are timeinvariant indications of the municipality's history. As my main interest in the analysis is the differences between municipalities, I use pooled OLS regression. The models show the bivariate relationships and the relationships including geographic, time-invariant, and historical economic covariates. As I expect the relationship between historical family formation structures and present-day outcomes to become weaker over time, I include fixed effects for the year of election in all panel regressions.

To model the suggested mechanism for transmission of norms over time, I model the relationship between historical family formation and presentday family formation (marriage rates, divorce rates, and spousal age gap), as well as the relationship between present-day family formation and gender balance in politics (corresponding to $\boldsymbol{H}_{2}$ and $\boldsymbol{H}_{3}$ ). I do this using pooled OLS regression for the 1988-2014 panels.

As a robustness test, I study the relationships over time. To do this, I estimate bivariate models using the historical averages but with separate models for each election between 1982 and 2014. These models are presented graphically and provide an overview of the relationships between historical family formation and present-day gender balance in politics. I expect the relationship to become weaker over time. An analysis of the models with family formation as the dependent variable is performed in the same way for 1988-2014.

\section{MAIN RESULTS: GENDER NORMS IN HISTORY AND THE SHARE OF WOMEN IN POLITICS TODAY}

The results of the regression models with gender balance among elected politicians and political candidates as dependent variables can be found in Table 2 and Table 3, respectively. As expected from the theory, the results show that in municipalities with a historically large proportion of unmarried women (Models 1 and 2) and a large proportion of women in the population (Models 3 and 4), indicating more progressive gender norms, larger proportions of women are nominated and elected to local political councils today. The relationship is somewhat stronger for municipalities with a historically large proportion of unmarried women than for those with a large proportion of women in general. 
Table 2. Historical gender norms and gender balance of politicians elected to municipal office

Unmarried

Women

Industry

Constant

Year fixed effects

Region fixed effects

Geographic covariates

Observations

Clusters

$R^{2}$
(1)

$\begin{array}{cc}0.523^{* * * * *} & 0.352^{* * * * * *} \\ (0.100) & (0.087)\end{array}$

(2)

$(0.087)$

$\begin{array}{cc}0.159^{* * * *} & 0.795^{* * * *} \\ (0.025) & (0.270) \\ \text { Yes } & \text { Yes } \\ \text { No } & \text { Yes } \\ \text { No } & \text { Yes } \\ 2,746 & 2,746 \\ 276 & 276 \\ 0.473 & 0.587\end{array}$

(3)

(4)

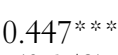

(0.158)

0.053
$(0.082)$
Yes
No
No
2,746
276
0.463

(5)

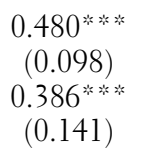

$(0.054)$

$0.714 * \cdots$
$(0.269)$
Yes
Yes
Yes
2,746
276
0.581

(6)

\begin{tabular}{cc}
$0.322 * * * *$ & $0.335^{* * * *}$ \\
$(0.086)$ & $(0.092)$ \\
$0.186^{* * * * *}$ & $0.180^{* * * *}$ \\
$(0.044)$ & $(0.041)$ \\
& $0.149 * * *$ \\
& $(0.059)$ \\
$0.680^{* * *}$ & $0.778^{* * * *}$ \\
$(0.270)$ & $(0.280)$ \\
Yes & Yes \\
Yes & Yes \\
Yes & Yes \\
2,746 & 2,490 \\
276 & 250 \\
0.589 & 0.590 \\
\hline
\end{tabular}

Notes: Results from OLS regression. The dependent variable is the proportion of women elected to municipality councils. Unmarried is the proportion of unmarried women, women is the proportion of women, and industry is the proportion of men who are employed in any type of industry from 1749 to 1859 . Year fixed effects are included for all election years from 1988 to 2014. Geographic covariates are coordinates for latitude and longitude (of the center of each municipality), and the (natural $\log$ of) the area of the municipality. Standard errors in parentheses clustered at level of municipality.

" $p<.1 ;{ }^{* * * 4} p<.05 ;$; $p<.01$.

Sources: Statistics Sweden and Tabellverket. 
Table 3. Historical norms and gender balance of politicians nominated to municipal office

Unmarried women

Women

$0.406^{* 2}$ 的米

Industry

Constant

Year fixed effects

Region fixed effects

Geographic covariates

Observations

Clusters

$R^{2}$
(1)

(0.070)

(2)

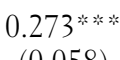

(0.058)

0.231 头水
$(0.017)$
Yes
No
No
2,753
276
0.374

$0.715^{*} \boldsymbol{w}^{2}$
$(0.184)$
Yes
Yes
Yes
2,753
276
0.521

(3)

\section{$0.229^{\text {**** * * }}$}

(0.100)

(4)

$0.210^{* \cdots *}$
$(0.052)$
Yes
No
No
2,753
276
0.347

(5)

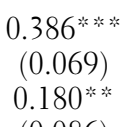

(0.044)

(0.086)

$0.697^{* * *} \cdot{ }^{*}$
$(0.190)$
Yes
Yes
Yes
2,753
276
0.510

(6)

(7)

\begin{tabular}{|c|c|c|}
\hline 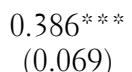 & 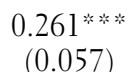 & 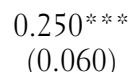 \\
\hline 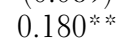 & 0.071 & 0.059 \\
\hline$(0.086)$ & $(0.044)$ & $\begin{array}{c}(0.048) \\
0.038 \\
(0.043)\end{array}$ \\
\hline $0.142^{2}$ & 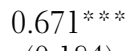 & 0.629 \\
\hline$(0.047)$ & $(0.184)$ & $(0.197)$ \\
\hline Yes & Yes & Yes \\
\hline No & Yes & Yes \\
\hline No & Yes & Yes \\
\hline 2,753 & 2,753 & 2,496 \\
\hline 276 & 276 & 250 \\
\hline 0.381 & 0.522 & 0.526 \\
\hline
\end{tabular}

Notes: Results from OLS regression. The dependent variable is the proportion of women nominated to municipality councils. Unmarried is the proportion of unmarried women, Women is the proportion of women, and Industry is the proportion of men who are employed in any type of industry from 1749 to 1859 . Year fixed effects are included for all election years from 1988 to 2014. Geographic covariates are coordinates for latitude and longitude (of the center of each municipality), and the (natural log of) the area of the municipality. Standard errors in parentheses clustered at level of municipality.

* $p<.1 ; * ; * 0<.05$; **; $p<.01$.

Sources: Statistics Sweden and Tabellverket. 
Including both independent variables of interest in the same model (Models 5 and 6) does not change the overall results; however, the proportion of unmarried women, once again, is a somewhat better predictor of the present-day gender balance in politics. In Model 7, the proportion of workers employed in industry from 1749 to 1859 is included as an additional covariate. As expected, there is a positive relationship between early industrialization and gender balance in politics. Yet, including historical employment in industry does not affect the main results.

The relationships show small but substantive correlations. In the most conservative model (Model 7), including time-invariant as well as economic covariates, a 1 percentage point increase in the proportion of unmarried women from 1749 to 1859 corresponds to a 0.34 percentage point increase in the proportion of women elected to municipal councils from 1988 to 2014.

In other words, the results show that in municipalities with $20 \%$ unmarried women in the population in the past, there are approximately $36 \%$ women in the municipal council today, compared with approximately $40 \%$ women in a municipal council in municipalities where there were $30 \%$ unmarried women in the past. The correlation between the share of women in the past and the share of women in politics today is somewhat weaker. In this case, a 1 percentage point increase in the proportion of women from 1749 to 1859 corresponds to a 0.18 percentage point increase in the share of women in municipal councils. Note that these relationships are substantially larger than the relationship between early industrialization and the present-day proportion of women in politics. A 1 percentage point increase in the share of employment in industry from 1749 to 1859 corresponds to a 0.15 percentage point increase in the proportion of women in municipal councils today.

These results are in line with $\boldsymbol{H}_{1}$, that historical gender norms matter for the present-day gender balance in politics. Where there was a large proportion of unmarried women and a large proportion of women in general from 1749 to 1859 , there were more women in politics from 1988 to 2014.

\section{THE LONG-TERM PERSISTENCE OF FAMILY FORMATION PATTERNS}

I study the suggested mechanism of family formation structures as the transmitter of social norms in two steps. First, I study the relationship 
between family formation and gender balance in politics from 1988 to 2014. Second, I study the relationship between historical social norms (1749-1859) and family formation today (1988-2014). If marriage markets transmit social norms across time, we should expect to see correlations between family formation patterns and gender balance in politics, and between historical social norms and present-day family formation patterns.

Table 4 and Table 5 show the results from pooled OLS regression models of the relationship between family formation and gender balance in politics from 1988 to 2014. The results show that where marriage rates are low, divorce rates are high, and the spousal age gap is small, there are more women in politics. Thus, where family formation patterns indicate more progressive gender norms, there is a larger share of women in the municipal councils. The results are more pronounced for the proportion of women elected (Models 1-9 in Table 4) than for the proportion of women among candidates (Models 1-9 in Table 5). ${ }^{14}$

Including all three family formation measures in the same model does not change the substantive interpretation of the results (Model 10). The estimates, however, are reduced in size. When all three measurements are included in the same model, the relationship between spousal age gap and the proportion of women nominated and elected changes the least compared with the models run separately for each type of family formation measure. This is expected, as marriage and divorce rates are related (the higher the marriage rate, the more possible divorces). Including the marriage rate in a model with the crude divorce rate can be thought of as a way of measuring the adjusted divorce rate.

The relationship sizes are small but substantive. Using the most conservative estimates in Model 10, the correlations can be interpreted as follows: in a municipality with a marriage rate of $65 \%$, the proportion of women in municipal office is estimated at $39 \%$, while in a municipality with a marriage rate of $30 \%$, the proportion of women in municipal council is estimated at $41 \%$. A divorce rate of $3 \%$ corresponds to $36 \%$ women in politics, and a divorce rate of $17 \%$ corresponds to $44 \%$ women in politics. An average spousal age gap of two years corresponds to $42 \%$ women in municipal councils, and an average spousal age gap of four years corresponds to $37 \%$ women in politics. These differences may seem small; however, compared with other estimates in the same model,

14. Including the municipal sex ratio for 1988-2014 does not substantially change the results (see the appendix, Section 2. 
Table 4. Family formation and gender balance of politicians elected to municipal office (1988-2014)

\begin{tabular}{|c|c|c|c|c|c|c|c|c|c|c|c|c|}
\hline & (1) & $(2)$ & (3) & (4) & (5) & (6) & (7) & (8) & (9) & (10) & (11) & $(12)$ \\
\hline Marriage rate & 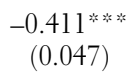 & $\begin{array}{c}-0.272 \text { *; } \\
(0.056)\end{array}$ & 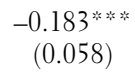 & & & & & & & 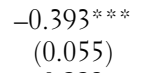 & $\begin{array}{c}-0.120^{*} \\
(0.062)\end{array}$ & $\begin{array}{l}-0.069 \\
(0.059)\end{array}$ \\
\hline Divorce rate & & & & $\begin{array}{c}0.923^{*} \text { *** } \\
(0.105)\end{array}$ & 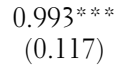 & 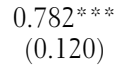 & & & & $\begin{array}{c}0.223 \\
(0.136)\end{array}$ & $\begin{array}{c}0.625^{\text {* }} \\
(0.165)\end{array}$ & 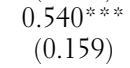 \\
\hline Age gap & & & & & & & 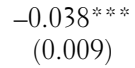 & 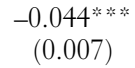 & 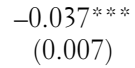 & 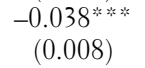 & 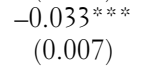 & 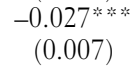 \\
\hline Population & & & $\begin{array}{c}0.000^{*} \text { * } \\
(0.000)\end{array}$ & & & 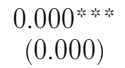 & & & 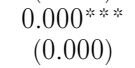 & & & $\begin{array}{c}0.000^{\text {* }}(0.000) \\
\left(0 . x^{2}\right.\end{array}$ \\
\hline Left parties & & & 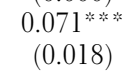 & & & 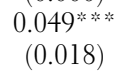 & & & 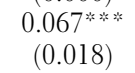 & & & 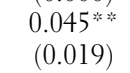 \\
\hline Average income & & & $\begin{array}{c}0.000^{*} ; * ; \\
(0.000)\end{array}$ & & & 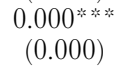 & & & $\begin{array}{c}0.000 \\
(0.000)\end{array}$ & & & $\begin{array}{l}0.000^{*} \\
(0.000)\end{array}$ \\
\hline Constant & 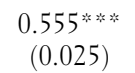 & 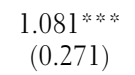 & 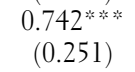 & $\begin{array}{c}0.260 \text { 头棌 } \\
(0.009)\end{array}$ & $\begin{array}{l}0.518^{\text {称况 }} \\
(0.236)\end{array}$ & $\begin{array}{c}0.370 \\
(0.227)\end{array}$ & 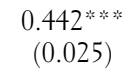 & $\begin{array}{c}0.505^{*} \text { 净 } \\
(0.250)\end{array}$ & $\begin{array}{c}0.378 \\
(0.233)\end{array}$ & 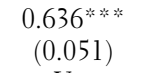 & $\begin{array}{c}0.574: 25 \\
(0.245)\end{array}$ & $\begin{array}{l}0.421^{*} \\
(0.240)\end{array}$ \\
\hline Year fixed effects & Yes & Yes & Yes & Yes & Yes & Yes & Yes & Yes & Yes & Yes & Yes & Yes \\
\hline Region fixed effects & No & Yes & Yes & No & Yes & Yes & No & Yes & Yes & No & Yes & Yes \\
\hline Geographic cov. & No & Yes & Yes & No & Yes & Yes & No & Yes & Yes & No & Yes & Yes \\
\hline Observations & 2,303 & 2,303 & 2,303 & 2,303 & 2,303 & 2,303 & 2,303 & 2,303 & 2,303 & 2,303 & 2,303 & 2,303 \\
\hline Clusters & 290 & 290 & 290 & 290 & 290 & 290 & 290 & 290 & 290 & 290 & 290 & 290 \\
\hline$R^{2}$ & 0.373 & 0.469 & 0.486 & 0.368 & 0.487 & 0.498 & 0.326 & 0.469 & 0.491 & 0.408 & 0.497 & 0.503 \\
\hline
\end{tabular}

Notes: Results from OLS regression. The dependent variable is the proportion of women elected to municipal councils. Married is the proportion of married women, divorced is the proportion of divorced women, and age gap is the average age difference between married women and their spouse. Population is the municipal population, left parties is the proportion of seats held by Social Democrats and the Left Party, and average income is the average income of the municipal population in Swedish kronor. Year fixed effects are included for all election years from 1988 to 2014. Geographic covariates are coordinates for latitude and longitude (of the center of each municipality), and the natural log of the area of the municipality. Standard errors in parentheses clustered at level of municipality. $* p<.1 ; * ; * 0<.05 ; * * * ; * 01$.

Sources: Statistics Sweden and Tabellverket. 
Table 5. Family formation and gender balance of politicians nominated to municipal office (1988-2014)

(4)

(5)

(6)

(7)

(8)

(9)

(10)

(11)

(12)

Marriage rate $\begin{array}{ccc}-0.253^{* * * * *} & -0.137^{* * * * * *} & -0.107^{* * * *} \\ (0.032) & (0.040) & (0.045)\end{array}$

Divorce rate $0.743^{* * * * *} 0.582^{* * * * *} 0.516^{* * * * *}$ $(0.077) \quad(0.094) \quad(0.103)$

$185 * 2 *$

$-0.019$

$-0.007$

$\begin{array}{lll}(0.038) & (0.050) \quad(0.052)\end{array}$

$0.402^{* * * *} \quad 0.476^{* * * *} \quad 0.453^{* * * *}$ $\begin{array}{rrrr} & (0.106) & (0.140) & (0.140) \\ -0.024^{* * * * *}-0.018^{* * * *}-0.019 * * * * & -0.015^{* * * *} & -0.010\end{array}$

Age gap

Population

$\begin{array}{ll}0.000 & 0.000\end{array}$

$-0.029^{* * * * *}$ $(0.007)$

$(0.007)$

$(0.007) \quad(0.008)$

(0.007)

$(0.007)$

$(0.000)$

$(0.000)$

$0.040^{\text {* * * * }}$

0.025

$(0.016) \quad(0.016)$

$0.039^{* * * *}$

$(0.000)$

Average income

$(0.000)$

Constant

$0.498^{* * * * *} \quad 0.876^{* * * * *} \quad 0.700$ *

$\begin{array}{ccc}0.303^{* * * * *} & 0.575^{* * * * *} & 0.474^{* * * *} \\ (0.007) & (0.190) & (0.190)\end{array}$

$(0.016)$
$0.000 *$

$0.000^{*}$

$(0.000)$

$\begin{array}{llllll}0.446^{* * * * *} & 0.577^{* * * *} & 0.497^{* * * *} & 0.485^{* * * *} & 0.540^{* * *} & 0.463^{* * *}\end{array}$

Year fixed effects

(0.017)

(0.202)

$0.199)$

$(0.007)$

(0.190)

Yes

(0.021)

$(0.202)$

(0.192)

$(0.040)$

$(0.212)$

No Yes Yes

effects

Geographic cov.

No $\quad$ Yes $\quad$ Yes

No Yes

Observations

No
2,303
290

Yes Yes

2,303

290

2,303

$\begin{array}{cc}\text { No } & \text { Yes } \\ 2,303 & 2,303 \\ 290 & 290\end{array}$

Yes

2,303

No
2,303
290

0.396

0.267

0.401

0.408

0.205

Yes
2,303
290
0.384

Yes
2,303
290
0.397

No

Yes

Yes

$\begin{array}{ccc}\text { No } & \text { Yes } & \text { Yes } \\ 2,303 & 2,303 & 2,303 \\ 290 & 290 & 290 \\ 0.287 & 0.405 & 0.410\end{array}$

Notes: Results from OLS regression. The dependent variable is the proportion of women nominated to municipal councils. Married is the proportion of married women, divorced is the proportion of divorced women, and age gap is the average age difference between married women and their spouse. Population is the municipal population, left parties is the proportion of seats held by Social Democrats and the Left Party, and average income is the average income in Swedish kronor of the municipal population. Year fixed effects are included for all election years in the time period from 1988 to 2014. Geographic covariates are coordinates for latitude and longitude (of the center of each municipality), and the natural log of the area of the municipality. Standard errors in parentheses clustered at level of municipality.

$* p<.1 ; * * *<<.05 ; * * * * * 01$.

Sources: Statistics Sweden and Tabellverket. 
the differences are not negligible. For example, the correlation between the proportion of left-party seats in the municipality and the number of women in politics shows that $10 \%$ left-party seats in a municipality corresponds to $38 \%$ women representatives, and $80 \%$ left-party seats corresponds to $41 \%$ women in the municipal council.

Table 6 shows the results from pooled OLS regression models of the relationship between historical family formation and present-day family formation. The results are in line with what is expected from the theory. Where there was a large share of women and/or a large share of unmarried women in the past, indicating more progressive gender norms, the present-day marriage rates are low, divorce rates high, and the spousal age gap relatively small. The substantive interpretation is the same regardless of whether estimating the models separately for the two historical measures or including both in the same model.

Once again, the correlation sizes are small but substantive. The strongest relationships are found between the share of unmarried women in the past and present-day marriage and divorce rates. When comparing the size of the estimates to the relationship between the proportion employed in industry from 1749 to 1859 and present-day family formation, the share of women and the share of unmarried women show correlations that are substantially larger.

The results are in line with the hypotheses. Where family formation patterns are traditional, there are fewer women in politics. Moreover, the results show that traditional family formation is persistent over time. Where family formation patterns were more traditional in the past, the family formation structure is more traditional today.

\section{MODELS BY ELECTION YEAR}

I reran the analysis by year of election (1982-2014). Estimating one model for each year complements the main results in two ways. First, I can rule out the possibility that the results are driven merely by within-municipality variation across time in the panel data. Second, it provides a good overview of the relationships over time. If historical norms are related to present-day outcomes, it can be expected that the relationships will be stronger in the earlier years of the panel. Figure 2 shows the regression coefficients from bivariate regression models of historical gender structures and present-day gender balance in politics. The coefficients are estimated from regression models, by year of election, and all use the 
Table 6. Historical norms and family formation today

\begin{tabular}{|c|c|c|c|c|c|c|c|c|c|c|c|c|}
\hline & \multicolumn{4}{|c|}{ Marriage Rate } & \multicolumn{4}{|c|}{ Divorce Rate } & \multicolumn{4}{|c|}{ Spousal Age Gap } \\
\hline & (1) & (2) & (3) & (4) & (5) & (6) & $(7)$ & (8) & (9) & (10) & (11) & $(12)$ \\
\hline $\begin{array}{l}\text { Unmarried } \\
\text { women }\end{array}$ & 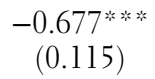 & & $\begin{array}{c}-0.576^{* * * *} \\
(0.141)\end{array}$ & 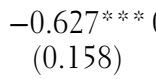 & 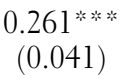 & & 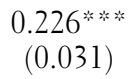 & $\begin{array}{c}0.217 * * \cdots \\
(0.033)\end{array}$ & 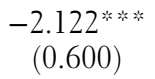 & & $\begin{array}{c}-1.849^{* * * *} \\
(0.730)\end{array}$ & $\begin{array}{c}-1.513 * \\
(0.804)\end{array}$ \\
\hline Women & & 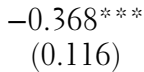 & 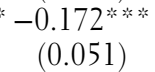 & 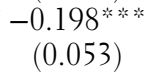 & & $\begin{array}{c}0.024 \\
(0.037)\end{array}$ & $\begin{array}{c}0.015 \\
(0.022)\end{array}$ & $\begin{array}{l}0.030^{*} \\
(0.018)\end{array}$ & & 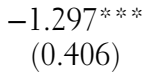 & $\begin{array}{c}-1.146 \% \\
(0.456)\end{array}$ & 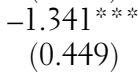 \\
\hline Industry & & & & $\begin{array}{l}-0.073 \\
(0.051)\end{array}$ & & & & $\begin{array}{l}0.049 * * ; \\
(0.025)\end{array}$ & & & & $\begin{array}{l}-0.447 \\
(0.331)\end{array}$ \\
\hline Constant & $\begin{array}{c}0.703 * \text { *** } \\
(0.027)\end{array}$ & $\begin{array}{c}0.731^{* * * *} \\
(0.061)\end{array}$ & $\begin{array}{c}1.423 \text { ***; } \\
(0.271)\end{array}$ & 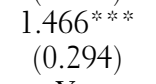 & $\begin{array}{c}0.016 \\
(0.010)\end{array}$ & $\begin{array}{c}0.067 \text { * } \\
(0.020)\end{array}$ & $\begin{array}{c}0.165 \\
(0.109)\end{array}$ & $\begin{array}{c}0.166 \\
(0.114)\end{array}$ & 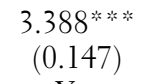 & $\begin{array}{c}3.551^{* * * * *} \\
(0.218)\end{array}$ & $\begin{array}{c}-3.725^{*} \\
(2.233)\end{array}$ & $\begin{array}{l}-4.268^{*} \\
(2.430)\end{array}$ \\
\hline $\begin{array}{l}\text { Year fixed } \\
\text { effects }\end{array}$ & Yes & Yes & Yes & Yes & Yes & Yes & Yes & Yes & Yes & Yes & Yes & Yes \\
\hline $\begin{array}{l}\text { Region fixed } \\
\text { effects }\end{array}$ & No & No & Yes & Yes & No & No & Yes & Yes & No & No & Yes & Yes \\
\hline $\begin{array}{l}\text { Geographic } \\
\text { cov. }\end{array}$ & No & No & Yes & Yes & No & No & Yes & Yes & No & No & Yes & Yes \\
\hline Observations & 2,205 & 2,205 & 2,205 & 1,998 & 2,205 & 2,205 & 2,205 & 1,998 & 2,205 & 2,205 & 2,205 & 1,998 \\
\hline Clusters & 276 & 276 & 276 & 250 & 276 & 276 & 276 & 250 & 276 & 276 & 276 & 250 \\
\hline$R^{2}$ & 0.494 & 0.426 & 0.700 & 0.698 & 0.573 & 0.510 & 0.775 & 0.780 & 0.112 & 0.087 & 0.423 & 0.428 \\
\hline
\end{tabular}

Notes: Results from OLS regression. The dependent variables, marriage rate, divorce rate and spousal age gap, are the proportion of married women, the proportion of divorced women, and the average age gap in married couples. Unmarried is the proportion of unmarried women, women is the proportion of women, and industry is the proportion of men who are employed in any type of industry from 1749 to 1859 . Year fixed effects are included for all election years from 1988 to 2014 Geographic covariates are coordinates for latitude and longitude (of the center of each municipality), and the (natural log of) the area of the municipality. Standard errors in parentheses clustered at level of municipality.

$* p<.1 ; * * ;<.05 ; * * * p<.01$.

Sources: Statistics Sweden and Tabellverket. 
Historical gender norms and gender balance in politics today
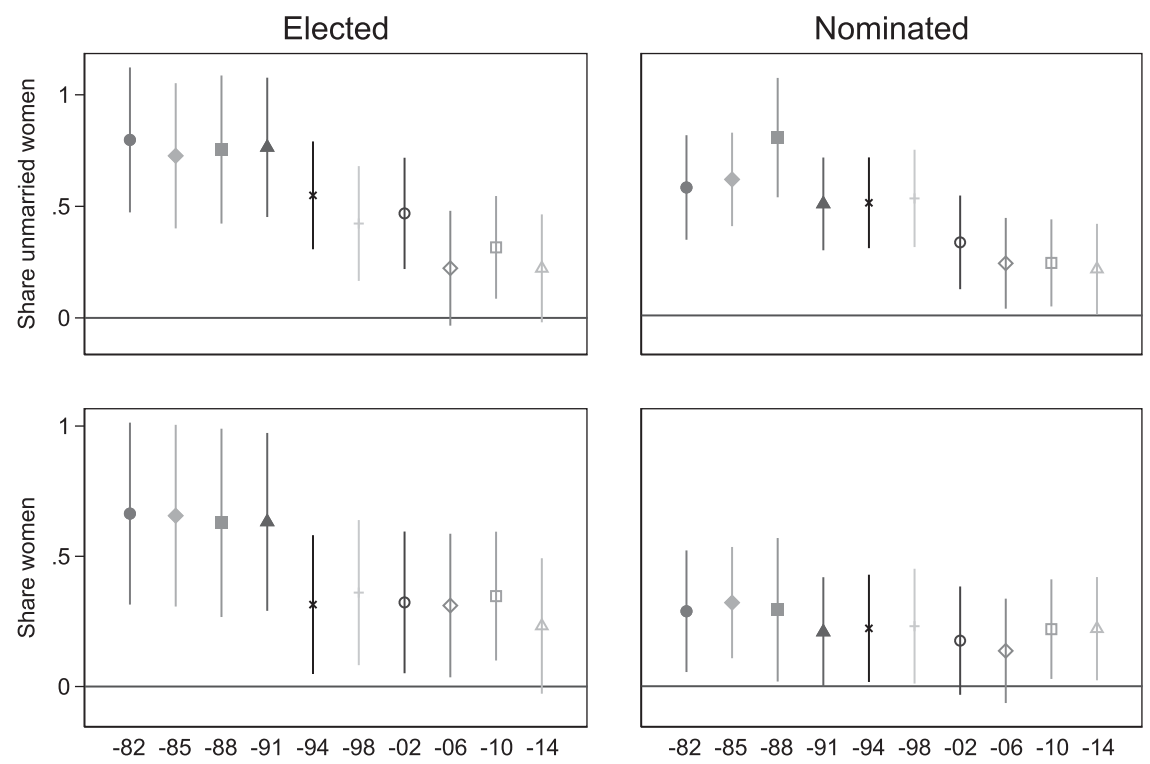

FiguRE 2. Historical gender norms and gender balance in local politics.

Coefficients from bivariate regression models, by year, all elections 1982-2014. Sources: Statistics Sweden and Tabellverket.

historical averages (1749-1859). The estimation of separate models supports the results from the panel regression models. In addition, the models separated by year show that the relationship between historical social structures and gender balance in politics is more pronounced in the earlier years of the present-day data. Note also the sharp difference in the size of the correlations before and after 1994. This corresponds to the introduction of zipper quotas in 1994 by many political parties. Figure 3 shows the regression coefficients from bivariate regression models of family formation and gender balance in politics, run separately, for all election years from 1988 to 2014.

Overall, the results are in line with what is expected from theory. Where the marriage rate is low, the divorce rate is high, and the spousal age gap is small, there are more women in politics. The results show that the relationship between family formation and gender balance in politics is most pronounced in the earlier years and gradually diminishes over time. The relationships are also more pronounced regarding the proportion of women elected than the proportion of women nominated. 
Family formation and gender balance in politics
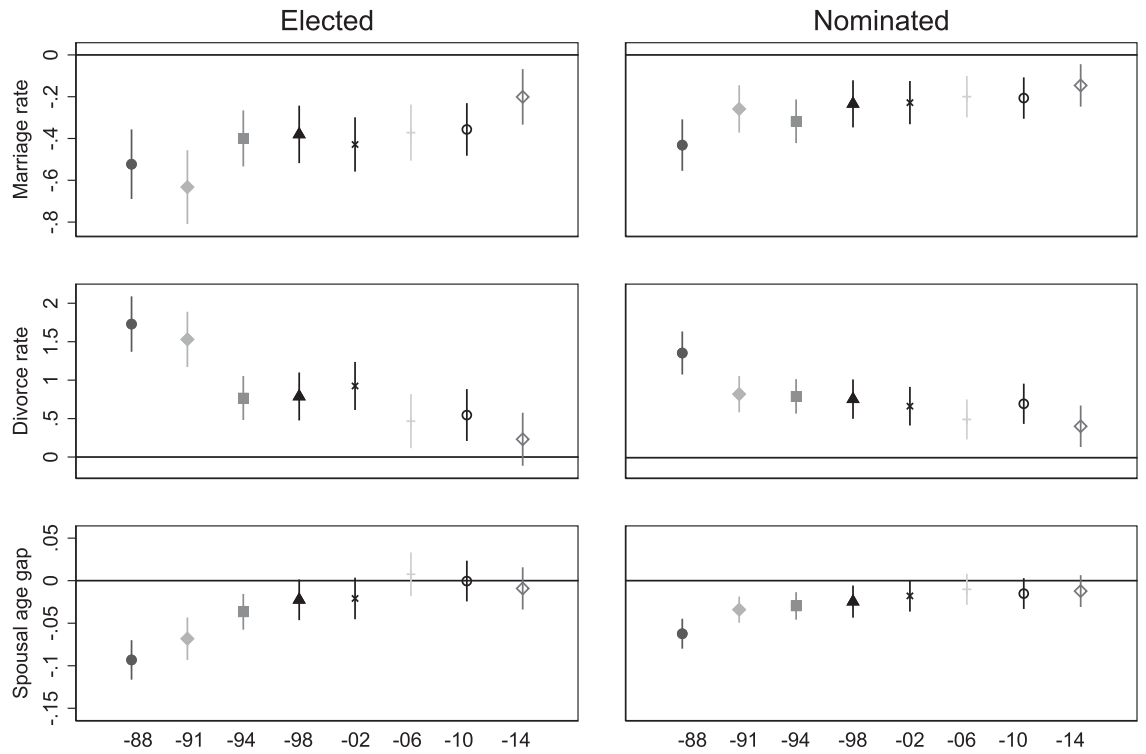

Figure 3. Family formation and gender balance in local politics. Coefficients from bivariate regression models by year for all elections 1982-2014.

Source: Statistics Sweden.

Figure 4 shows the coefficients from regression models, by year, for the relationship between historical social norms and present-day family formation patterns. The three dependent variables are marriage rate, divorce rate, and spousal age gap, and the two independent variables are the proportion of women and the proportion of unmarried women. The historical proportion of women is negatively correlated with the marriage rate and positively correlated with the spousal age gap, and there is a tendency toward a positive correlation with the divorce rate in the early years. The proportion of unmarried women in the past is negatively correlated with the marriage rate, positively correlated with the divorce rate, and positively correlated with the (negative) age gap in couples. The results are somewhat more pronounced in the earlier years; however, there are less pronounced differences between the years than in the relationship between the historical measurements and the presentday gender balance in politics.

The results from the models with separate regression models for each panel year support the main results. The results show that the relationships are more pronounced in the earlier years. 
Historical gender norms and family formation
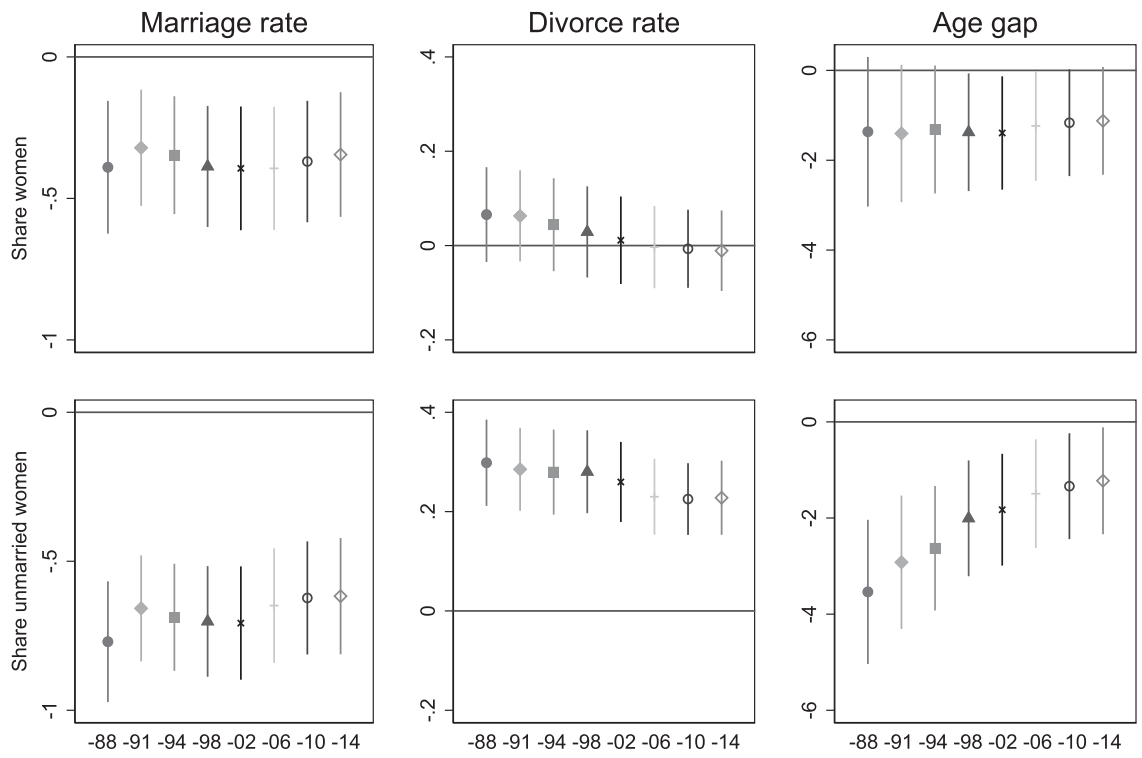

FIgURE 4. Historical gender norms and family formation today. Coefficients from bivariate regression models by year for all elections 1988-2014.

Sources: Statistics Sweden and Tabellverket.

\section{INTERPRETATION OF THE RESULTS AND ALTERNATIVE EXPLANATIONS}

Can the results be interpreted as the persistence of social norms? Is family formation a likely mechanism of norm transmission? To answer these questions, I conduct three additional tests. First, to assess whether family formation patterns are reasonable proxies for social norms, I correlate the present-day family formation measurements with survey measurements. The survey data, although pooled from many years, yield only a few answers from each municipality, and there is not much variation across municipalities. Despite these shortcomings, the results show that the survey measurement of norms is correlated with the family formation measurements, all in the expected directions (see Section 2 of the appendix in the supplementary material online).

Second, I reran the analysis with present-day gender balance in the labor market instead of present-day family formation structures (see the appendix, Section 2) as the dependent variable and the historical measurements as 
the independent variables. The results show that there is a relationship between the share of women in the past and the share of women in the labor force today. However, there is no such relationship between the share of unmarried women in the past and the share of women in the labor force today. Thus, this test can be seen as strengthening the argument of the relevance of marriage markets as transmitters of norms across time.

Third, to assess the relative importance of historical compared with current family formation norms, I include two models with present-day gender balance in politics (elected and nominated) as the dependent variable and both the historical and present-day measurements of family formation as independent variables (see the appendix, Section 2). If family formation transmits social norms across time, a large part of the relationship between historical social norms and present-day gender balance ought to be accounted for in such a model. The results show that the correlations between the historical measurements of family formation and the present-day gender balance in politics are reduced in size when present-day family formation measurements are included.

The results from the first test support the use of the proxy variables for measuring social norms. The second and third tests support the idea of family formation as a likely transmitter of norms across time.

\section{DISCUSSION}

In this article, I set out to study why some societies reach a higher level of gender equality in politics than others. The results show that there is more gender balance in local politics from 1982 to 2014, where historical gender norms were less traditional, and that family formation is a likely mechanism for the transmission of social norms across time. The results are in line with previous research finding that social norms are persistent across time (Alesina, Giuliano, and Nunn 2013), that family formation is important for gender balance in political office (Bernhard, Shames, and Teele 2020; Folke and Rickne 2020), and that family formation is one mechanism for the transmission of social norms across time (Fernández, Fogli, and Olivetti 2004). Moreover, the findings complement previous research in several ways. First, the analysis in this article goes further back in history to study the relationship between historical family formation and present-day gender balance in political representation. Second, it highlights family formation as a long-term mechanism of 
norm transmission. Third, it shows that historical persistence should not be neglected when studying gender balance in politics today.

There are some important limitations of this study. First, I provide no causal identification of the reason behind the variation in historical social norms. Second, using data very far back in time is advantageous; however, there is uncertainty because of the long gap between the historical data and the present-day data. Third, the study can only provide suggestive support of the mechanism of family formation for the transmission of social norms, as it cannot rule out other explanations. Some of the most likely competing theories of norm transmission over time are through politics itself or through the labor market. The first alternative is only a logical explanation for a small part of the time period covered as women's access to municipal councils and the introduction of democracy did not take place until early twentieth century. The second alternative is a possible contender for the entire period. Yet, labor markets change more quickly than marriage markets, and in the case that labor markets are persistent across time, this ought to reinforce family formation structures. Finally, using proxy variables to study social norms, I cannot rule out possible explanations other than social norms for the persistence of social structures. For example, some municipalities may have started out with a resource advantage that affected family structures, and this advantage persisted over time. This is not an unlikely scenario, however, and path dependency in resources and social norms of family formation ought to be seen as mutually reinforcing mechanisms rather than mutually exclusive.

I suggest that these limitations provide fruitful avenues for future research. First, studies looking into the causes of historical variation in norms could complement the results of this article, providing a deeper understanding of why local variation in social norms has emerged. Variation in the share of women and the share of unmarried women in the past can have many different explanations, which could account for the emergence of gender norms. For example, the historical gender balance may be explained by the overrepresentation of men in emigration and male enlistment in war.

Second, future research could provide insights into stability and change in social norms by including the years between the preindustrial era and the present day, for example, by studying the role of industrialization in forming and changing social norms, because the type of industry may matter in the development of gender norms. It could be that different types of industry attract and develop different labor market structures and different gender norms. 
Third, future research studying the mechanism of norm transmission across generations in more detail, looking into the role of family formation, would complement the descriptive results of this article. Fourth, future research disentangling the role of social norms compared with other types of path dependency in transmitting behavior across generations is necessary. For example, it would be fruitful to understand the role of intergenerational transmission of resources compared to the transmission of norms.

This article cannot identify the reason behind the historical variation; yet, we can draw valuable conclusions from the results. Most importantly, the results show that we should not overlook historical legacies or family formation patterns when studying gender balance in political representation. Traditional norms can explain both women's lower political ambition (Lawless 2005), women's larger structural constraints (Bernhard, Shames, and Teele 2020; Folke and Rickne 2020), and lower demand for women in politics (Gimenez et al. 2018; Teele, Kalla, and Rosenbluth 2018). If we find that gendered structures of family formation matter for the number of women in politics in one of the most gender-equal countries in the world, Sweden, it is likely that this is also the case in less equal settings.

Moreover, the article contributes to our understanding of persistence and change. When looking at the relationship between gender balance in the past and gender balance in politics in the 1980s, the results show the persistence of norms. However, the decline of such persistence since the 1990s is striking. In other words, we know from the results of this article that although gender norms can persist over several centuries, large changes can take place during a decade. When stricter rules about gender equality were imposed from the outside, historical persistence declined.

Moa Frödin Gruneau is a Postdoctoral Researcher in the Department of Political Science, University of Gothenburg, Gothenburg, Sweden: moa. frodin.gruneau@gu.se

\section{SUPPLEMENTARY MATERIAL}

To view supplementary material for this article, please visit https:/doi.org/ $10.1017 / \mathrm{S} 1743923 \mathrm{X} 21000106$. 


\section{REFERENCES}

Acharya, Avidit, Matthew Blackwell, and Maya Sen. 2016. "The Political Legacy of American Slavery." Journal of Politics 78 (3): 621-41.

Aguilar-Gomez, Sandra, and Anja Benshaul-Tolonen. 2018. "Norms Formation: The Gold Rush and Women's Roles." https://papers.ssrn.com/sol3/papers.cfm?abstract_id= 3284515 (accessed March 28, 2021).

Akerlof, George A., and Rachel E. Kranton. 2000. “Economics and Identity." Quarterly Journal of Economics 115 (3): 715-53.

Alesina, Alberto, Paola Giuliano, and Nathan Nunn. 2013. "On the Origins of Gender Roles: Women and the Plough.” Quarterly Journal of Economics 128 (2): 469-530.

Antecol, Heather. 2000. "An Examination of Cross-Country Differences in the Gender Gap in Labor Force Participation Rates.” Labour Economics 7 (4): 409-26.

Baranov, Victoria, Ralph De Haas, and Pauline A. Grosjean. 2018. "Men: Roots and Consequences of Masculinity Norms." Discussion Paper 2018-041, Tilburg University, Center for Economic Research. https://papers.ssrn.com/sol3/papers.cfm? abstract_id=3266457 (accessed March 28, 2021).

Becker, Gary S. 1973. “A Theory of Marriage: Part I.” Joumal of Political Economy 81 (4): 813-46.

Bernhard, Rachel, Shauna Shames, and Dawn Langan Teele. 2020. "To Emerge? Breadwinning, Motherhood, and Women's Decisions to Run for Office." American Political Science Review. Published online November 17. https://doi.org/10.1017/ S0003055420000970.

Bertrand, Marianne, Patricia Cortés, Claudia Olivetti, and Jessican Pan. 2016. "Social Norms, Labor Market Opportunities, and the Marriage Gap for Skilled Women." Working Paper 22015, National Bureau of Economic Research. https://www.nber.org/ papers/w22015 (accessed March 28, 2021).

Bertrand, Marianne, Emir Kamenica, and Jessica Pan. 2015. "Gender Identity and Relative Income within Households." Quarterly Journal of Economics 130 (2): 571-614.

Blau, Francine D., Lawrence M. Kahn, Albert Yung-Hsu Liu, and Kerry L. Papps. 2013. “The Transmission of Women's Fertility, Human Capital, and Work Orientation across Immigrant Generations." Journal of Population Economics 26 (2): 405-35.

Boschini, Anne, Christina Hakansson, Asa Rosén, and Anna Sjogren. 2011. "Trading Off or Having It All? Completed Fertility and Mid-Career Earnings of Swedish Men and Women." https://papers.ssm.com/sol3/papers.cfm?abstract_id=1954668 (accessed March 28, 2021).

Boserup, Ester. 1970. Woman's Role in Economic Development. London: Routledge.

Brodeur, Abel, and Joanne Haddad. 2018. "Institutions, Attitudes and LGBT: Evidence from the Gold Rush.” Discussion Paper 11957, Institute of Labor Economics. https:// www.iza.org/publications/dp/11957/institutions-attitudes-and-lgbt-evidence-from-the-goldrush (accessed March 28, 2021).

Broms, Rasmus, and Andrej Kokkonen. 2019. "Inheritance Regimes: Medieval Family Structures and Current Institutional Quality." Governance 32 (4): 619-37.

Esping-Andersen, Gøsta, and Francesco C. Billari. 2015. "Re-theorizing Family Demographics." Population and Development Review 41 (1): 1-31.

Fernández, Raquel. 2013. "Cultural Change as Learning: The Evolution of Female Labor Force Participation over a Century.” American Economic Review 103 (1): 472-500.

Fernández, Raquel, and Alessandra Fogli. 2009. "Culture: An Empirical Investigation of Beliefs, Work, and Fertility.” American Economic Joumal: Macroeconomics 1 (1): 146-77.

Fernández, Raquel, Alessandra Fogli, and Claudia Olivetti. 2004. "Mothers and Sons: Preference Formation and Female Labor Force Dynamics." Quarterly Journal of Economics 119 (4): 1249-99. 
Folke, Olle, and Johanna Rickne. 2020. "All the Single Ladies: Job Promotions and the Durability of Marriage.” American Economic Journal: Applied Economics 12 (1): 260-87.

Forsberg, Gunnel. 1997. "Rulltrapperegioner och social infrastruktur" [Escalator regions and social infrastructure]. In Om makt och kön: I spåren av offentliga organisationers omvandling [Power and gender], edited by Elisabeth Sundin, 31-41. Stockholm: Swedish Government Reports.

Fox, Richard L., and Jennifer L. Lawless. 2004. "Entering the Arena? Gender and the Decision to Run for Office." American Journal of Political Science 48 (2): 264-80.

Freidenvall, Lenita. 2006. "Vägen till Varannan damernas: Om kvinnorepresentation, kvotering och kandidaturval i svensk politik 1970-2002." [Every other one for the ladies: Women's political representation, gender quotas and candidate selection in Swedish politics 1970-2002]. PhD diss., Stockholm University.

Gimenez, Alejandra Teresite, Christopher F. Karpowitz, J. Quin Monson, and Jessica Robinson Preece. 2018. "The Double Bind Still Constricts: Gendered Self-Presentation and Electoral Success in Republican Neighborhood Caucuses." http://gcel.byu.edu/ Content/Publications/Double-Blind-SPSA-Manuscript.pdf (accessed March 31, 2021).

Giuliano, Paola. 2015. "The Role of Women in Society: From Preindustrial to Modern Times." CESifo Economic Studies 61 (1): 33-52.

- 2017. "Gender: A Historical Perspective." In The Oxford Handbook of Women and the Economy, edited by Susan L. Averett, Laura M. Argys, and Saul D. Hoffman. Oxford: Oxford University Press. 10.1093/oxfordhb/9780190628963.013.29.

Goldscheider, Frances, Eva Bernhardt, and Trude Lappegård. 2015. "The Gender Revolution: A Framework for Understanding Changing Family and Demographic Behavior." Population and Development Review 41 (2): 207-39.

Hansen, Casper, Peter Jensen, and Christian Skovsgaard. 2015. "Modern Gender Roles and Agricultural History: The Neolithic Inheritance." Journal of Economic Growth 20 (4): 365-404.

Homola, Jonathan, Miguel M. Pereira, and Margit Tavits. 2020. "Legacies of the Third Reich: Concentration Camps and Out-Group Intolerance." American Political Science Review 114 (2): 1-18.

Iversen, Torben, and Frances Rosenbluth. 2010. Women, Work, and Politics: The Political Economy of Gender Inequality. New Haven, CT: Yale University Press.

Jennings, M. Kent. 2007. "Political Socialization." In The Oxford Handbook of Political Behavior, edited by Russell J. Dalton and Hans-Dieter Klingemann. Oxford: Oxford University Press. 10.1093/oxfordhb/9780199270125.003.0002.

Kittilson, Miki Caul. 2006. Challenging Parties, Changing Parliaments: Women and Elected Office in Contemporary Western Europe. Columbus: Ohio State University Press.

Lawless, Jennifer L. 2005. It Takes a Candidate: Why Women Don't Run For Office. Cambridge: Cambridge University Press.

Lovenduski, Joni, and Pippa Norris. 1993. Gender and Party Politics. London: Sage.

Lundh, Christer. 2013. “The Geography of Marriage.” Scandinavian Journal of History 38 (3): 318-43.

Manning, Patrick. 1990. Slavery and African Life: Occidental, Oriental and African Slave Trades. Cambridge: Cambridge University Press.

Mazumder, Soumyajit. 2018. "The Persistent Effect of US Civil Rights Protests on Political Attitudes." American Journal of Political Science 62 (4): 922-35.

McDonald, Peter. 2000. "Gender Equity in Theories of Fertility Transition." Population and Development Review 26 (3): 427-39.

Morgan-Collins, Mona, and Grace Natusch. 2020. "At the Intersection of Gender and Class: How Were Newly Enfranchised Women Mobilized in Sweden?" https:// 
5689e5b0-4cl1-4d83-9cd6-33b7fl0dcedd.filesusr.com/ugd/delfc0_

5d73b5a64cc240128a2d45d7068db621.pdf (accessed March 28, 2021).

Norris, Pippa, and Joni Lovenduski. 1995. Political Recruitment: Gender, Race and Class in the British Parliament. Cambridge: Cambridge University Press.

Olivetti, Claudia, and Barbara Petrongolo. 2016. "The Evolution of Gender Gaps in Industrialized Countries." Annual Review of Economics 8: 405-34.

Pessin, Léa. 2018. "Changing Gender Norms and Marriage Dynamics in the United States." Journal of Marriage and Family 80 (1): 25-41.

Rotering, Paul, and Hilde Bras. 2019. "The Age Difference between Spouses and Reproduction in 19th Century Sweden." Demographic Research 41: 1059-90.

Simonsson, Per, and Glenn Sandström. 2011. "Ready, Willing, and Able to Divorce: An Economic and Cultural History of Divorce in Twentieth-Century Sweden." Journal of Family History 36 (2): 210-29.

Sjoberg, Ola. 2004. "The Role of Family Policy Institutions in Explaining Gender-Role Attitudes: A Comparative Multilevel Analysis of Thirteen Industrialized Countries." Journal of European Social Policy 14 (2): 107-23.

Stevenson, Betsey, and Justin Wolfers. 2007. "Marriage and Divorce: Changes and Their Driving Forces." Journal of Economic Perspectives 21 (2): 27-52.

Tabellverket. 2018. "Demografiska databasen" [Demographic database]. Centre for Demographic and Ageing Research, Umeå University.

Teele, Dawn Langan, Joshua Kalla, and Frances Rosenbluth. 2018. "The Ties That Double Bind: Social Roles and Women's Underrepresentation in Politics." American Political Science Review 112 (3): 525-41.

Teso, Edoardo. 2018. "The Long-Term Effect of Demographic Shocks on the Evolution of Gender Roles: Evidence from the Transatlantic Slave Trade." Journal of the European Economic Association 17 (2): 497-534.

Verba, Sidney, Kay Lehman Schlozman, and Nancy Burns. 2005. "Family Ties: Understanding the Intergenerational Transmission of Participation." In The Social Logic of Politics, edited by Alan Zuckerman, 95-114. Philadelphia: Temple University Press.

Wängnerud, Lena. 2009. "Woman in Parliaments: Descriptive and Substantive Representation." Annual Review of Political Science 12: 51-69.

Westholm, Anders. 1991. The Political Heritage: Testing Theories of Family Socialization and Generational Change. Uppsala: Uppsala University.

Westholm, Anders, and Richard G. Niemi. 1992. "Political Institutions and Political Socialization: A Cross-National Study." Comparative Politics 25 (1): 25-41. 